\title{
Hubungan Tingkat Intelligence Qoutient (IQ) dan Bakat dengan Hasil Kejuaraan Senam POPDA DIY
}

\author{
Neva Widanita ${ }^{1}{ }^{\bowtie}$ Endang Rini Sukamti $^{2}$, Rifqi Festiawan ${ }^{1}$ \\ ${ }^{1}$ Program Studi Pendidikan Jasmani, Fakultas Ilmu-Ilmu Kesehatan, Universitas Jenderal Soedirman, \\ Indonesia \\ ${ }^{2}$ Program Studi Pendidikan Kepelatihan Olahraga, Kesehatan dan Rekreasi, Fakultas Ilmu Keolahragaan, \\ Universitas Negeri Yogyakarta, Indonesia
}

\begin{tabular}{l}
\hline Info Artikel \\
\hline Kata Kunci: \\
Bakat, kecerdasan intelektual, \\
POPDA DIY, prestasi \\
Keywords: \\
Talent, IQ, POPDA DIY, \\
achievement \\
\hline Alamat korespondensi: \\
Gedung Kuliah PJKR, \\
Karangwangkal, Purwokerto \\
Utara, Banyumas, 53113 \\
E-mail: \\
rifai.festiawan@unsoed.ac.id
\end{tabular}

\begin{abstract}
Abstrak
Penelitian ini bertujuan untuk mengetahui hubungan tingkat IQ dan bakat dengan hasil kejuaraan POPDA senam di DIY. Metode yang digunakan adalah survei, dengan teknik pengumpulan data menggunakan tes dan pengukuran. Populasi dalam penelitian ini adalah seluruh atlet senam artistik dan ritmik yang mengikuti kejuaraan POPDA senam di Yogyakarta. Sampel yang diambil dari hasil purposive sampling, berjumlah 16 atlet. Analisis data menggunakan uji regresi korelasi. Hasil penelitian menunjukkan bahwa (1) tidak ada hubungan antara tingkat Intelligence quotient dengan hasil kejuaraan senam POPDA DIY, dengan nilai $\mathrm{r}$ hitung sebesar $0.187<0.400 \mathrm{r}$ tabel dengan $\mathrm{n}=16$ pada signifikansi $5 \%$, (2) Ada hubungan antara bakat dengan hasil kejuaran senam POPDA DIY, dengan nilai $r$ hitung sebesar $0.956>$ $0.400 \mathrm{r}$ tabel dengan $\mathrm{n}=16$ pada signifikansi $5 \%$, (3) Ada hubungan antara tingkat Intelligence quotient dan bakat terhadap hasil kejuaran senam POPDA DIY, dengan F hitung (113.316) > (3.806) F tabel pada $\alpha=5 \%$. Dari hasil penelitian ini dapat disimpulkan bahwa ada hubungan antara tingkat Intelligence quotient dan bakat terhadap hasil kejuaran senam POPDA DIY sehingga hasil ini bisa menjadi salah satu acuan dalam meningkatkan prestasi khususnya di cabang olahraga senam.
\end{abstract}

\begin{abstract}
This study aims to determine the relationship of IQ and talent levels with the POPDA gymnastics championship results in DIY. The method used is a survey, with data collection techniques using tests and measurements. The population in this study were all artistic and rhythmic gymnastics athletes who participated in the POPDA gymnastics championship in Yogyakarta. Samples taken from the results of purposive sampling, amounting to 16 athletes. Data analysis using correlation regression test. The results showed that (1) there was no relationship between the intelligence quotient level with the results of the DIY POPDA gymnastics championship, with a calculated $r$ value of $0.187<0.400 r$ table with $n=16$ at a significance of 5\%, (2) There was a relationship between talent and the outcome of the championship POPDA DIY gymnastics, with a calculated $r$ value of $0.956>0.400 r$ table with $n=16$ at a significance of 5\%, (3) There is a relationship between the level of Intelligence quotient and talent on the results of POPDA DIY gymnastics, with an F count (113.316)> (3.806) ) $F$ table at $\alpha=5 \%$. From the results of this study it can be concluded that there is a relationship between the level of Intelligence quotient and talent on the results of the DIY POPDA gymnastics championship so that these results can be one of the references in improving achievement, especially in gymnastics.
\end{abstract}




\section{PENDAHULUAN}

Tingkat kecerdasan dan bakat penting untuk meraih prestasi dalam olahraga hingga akhirnya dilakukan penelitian untuk mengetahui hubungan antara tingkat kecerdasan dan bakat yang dimiliki dengan hasil kejuaraan. Penulis beranggapan bahwa tingkat kecerdasan dan bakat akan berpengaruh terhadap keterampilan gerak dan hasil kejuaraan.

Dalam kehidupan modern ini manusia tidak dapat dipisahkan dengan olahraga (Festiawan, 2020). Baik sebagai arena kompetisi maupun sebagai kebutuhan untuk menjaga tubuh agar tetap sehat. Olahraga senam termasuk salah satu jenis olahraga yang populer dan banyak digemari oleh masyarakat Indonesia. Senam dapat dilakukan oleh berbagai kalangan dari anak muda sampai usia lanjut (American Sport Education Program and USA Gymnastics, 2011)

Selain keterampilan gerak dalam melakukan gerakan senam, tingkat kecerdasan dan bakat sangat memengaruhi siswa dalam mempelajari dan melakukan elemen gerakan dalam senam. Menghafal gerakan senam berhubungan dengan kreativitas yang dimiliki seseorang (Abbott et al., 2002). Kreativitas dapat digambarkan sebagai kemampuan untuk menciptakan dan menghasilkan suatu gerakan yang baru (Preckel, Holling and Wiese, 2006). Semakin cerdas siswa tersebut maka semakin mudah menerima dan mencerna materi yang telah diberikan. Begitu pula dengan bakat yang telah dimiliki seorang siswa. Kecerdasan dan bakat secara signifikan berhubungan/berkorelasi positif dengan capaian kinerja (Makel et al., 2015).

Bakat dalam olahraga diperoleh dari factor genetik dan metode latihan (Tucker and Collins, 2012). Apabila atlet mempunyai bakat dalam bidang olahraga khususnya cabang senam maka dengan mudah dia dapat mengikuti elemen gerakan yang telah diberikan seorang pelatih. Kecerdasan dan bakat sangat diperlukan untuk membina atlet menjadi seorang atlet yang professional. karena hal tersebut sangat mendukung siswa untuk menangkap materimateri yang diberikan seorang pelatih (Fazari, Damayanti and Rahayu, 2017).

Pembibitan dalam olahraga dilakukan sejak dini. Latihan yang dilakukan sejak dni bertujuan untuk mencetak atlet yang professional di masa datang. Atlet senam dibentuk sejak kecil karena komponen fisik yang dilatih salah satunya adalah kelentukan. Penilaian yang cermat atas kemampuan fisik pesenam muda sejak usia dinisangat penting untuk karir yang sukses di masa mendatang (Mkaouer et al., 2018).

Pekan olahraga pelajar daerah (POPDA) merupakan multi even pelajar tahunan yang merupakan titik kulminasi dan gambaran pembinaan prestasi olahraga pelajar daerah dengan mempertandingkan banyak cabang. Selain sebagai salah satu alat pemersatu dikalangan pelajar, POPDA bertujuan untuk meningkatkan pemasalan, pembibitan, dan pembinaan atlet berbakat yang nantinya diharapkan mampu berprestasi di tingkat nasional, regional maupun internasional. Perlombaan ini diperuntukkan bagi atlet daerah yang masih menyandang status pelajar SMPSMA. Perlombaan ini bertujuan untuk memunculkan bibit atlet senam baru di Yogyakarta. Dalam setiap penjurian lomba sudah terlihat atlet yang berbakat dalam bidang senam ataupun tidak, tetapi dalam hal kecerdasan intelegensi dan kecerdasan emosi belum dapat terlihat apakah terdapat hubungan antara tingkat IQ dan bakat terhadap hasil kejuaraan. Atlet tidak akan menjadi atlet profesional jika tidak didukung dengan kecerdasan intelegensi dan bakat yang selalu dilatih

Pelajar yang berbakat dan berbakat didefinisikan sebagai mereka yang memiliki satu atau lebih kemampuan yang dikembangkan ke tingkat yang jauh lebih tinggi daripada kelompok tahun mereka (atau dengan potensi untuk mengembangkan kemampuan itu). Berbakat( gifted) menjelaskan pelajar yang memiliki kemampuan untuk unggul secara akademis dalam satu atau lebih mata pelajaran seperti bahasa Inggris, drama, teknologi berhubungan dengan kecerdasan otak. Bakat (talented) menggambarkan peserta didik yang memiliki kemampuan untuk unggul dalam keterampilan praktis seperti olahraga, kepemimpinan, kinerja artistik, atau dalam keterampilan terapan. (Endepohls-Ulpe, 2009)

Identifikasi bakat dalam senam sangat penting dilakukan sejak dini, oleh karena itu pemahaman baik yang baik tentang faktor-faktor yang memengaruhi perkembangan pesenam 
harus diperhatikan (Pion et al., 2015). Atlet biasanya kurang memahami potensi yang ada dalam diri masing-masing. Hingga akhirnya atlet tidak percaya diri melakukan sesuatu hal. Kecerdasan intelegensi yang terdapat pada diri seseorang merupakan kecerdasan umum yang melandasi semua hal yang dilakukan. Dari cara berbicara, menghitung, menghafal, dan beraktifitas. Seperti dalam bidang olahraga senam. Olahraga senam merupakan olahraga yang berkaitan dengan ketepatan, keindahan, dan kemampuan mengingat rangkaian gerak (Werner, Williams and Hall, 2012). Seperti dalam senam ritmik dan senam artistik. Atlet diberikan rangkain gerak yang sudah terdapat elemen dan gerakan tambahan (International Gymnastics Federation (F.I.G), 2016).

Kemampuan atlet dalam mengingat suatu rangkaian gerakan dan ketepatan gerak untuk mengikuti alunan musik termasuk dalam kecerdasan intelegensi. Kemampuan yang dimiliki setiap atlet berbeda-beda hingga akhirnya hasil yang didapat dalam kejuaraan pun berbeda. Selain kecerdasan intelegensi, bakat juga berpengaruh terhadap hasil kejuaraan. Bakat yang selalu diasah dan dilatih menjadikan seseorang lebih terampil dalam melakukan setiap hal yang dilakukan.

Kecerdasan intelegensi dan bakat merupakan hal yang sangat penting dalam membina atlet menjadi atlet yang professional. Terdapat penelitian dari (Andiri, Jajat and Sultoni, 2017) terkait tentang tingkat kecerdasan emosional dan prestasi akademik mahasiswa. Hasil dari penelitian tersebut yaitu terdapat hubungan yang positif antara kedua variabel tersebut. Dalam hal ini penulis ingin melakukan penelitian mengenai hubungan antara intelligence quotient dan bakat terhadap hasil kejuaraan POPDA senam. Penelitian ini bertujuan untuk mengetahui apakah terdapat hubungan antara kecerdasan intelegensi dan bakat terhadap hasil kejuaraan. Hasil penelitian ini dimaksudkan untuk memberikan pengetahuan dan pedoman bagi atlet dan pelatih untuk memperhatikan juga tingkat kecerdasan intelegensi dan bakat sebagai patokan dalam membina atlet dalam jangka panjang.

\section{METODE}

\section{Metode dan Desain}

Penelitian ini merupakan penelitian deskriptif yaitu penelitian yang semata-mata bertujuan mengetahui keadaan objek atau peristiwa tanpa suatu maksud untuk mengambil kesimpulankesimpulan yang berlaku secara umum (Sutrisno Hadi, 1978: 3). Metode yang digunakan adalah tes untuk mengetahui kemampuan atlet dalam mengikuti perlombaan senam, teknik pengumpulan data dengan menggunakan tes pengukuran. Penelitian ini bertujuan untuk mengetahui ada tidaknya hubungan intelligence quotient dan bakat terhadap hasil kejuaraan. Desain variabel penelitian ini adalah hubungan tunggal-ganda antara variabel bebas $(\mathrm{X})$ dengan variabel terikat $(Y)$. Adapun desain penelitian ini adalah sebagai berikut:

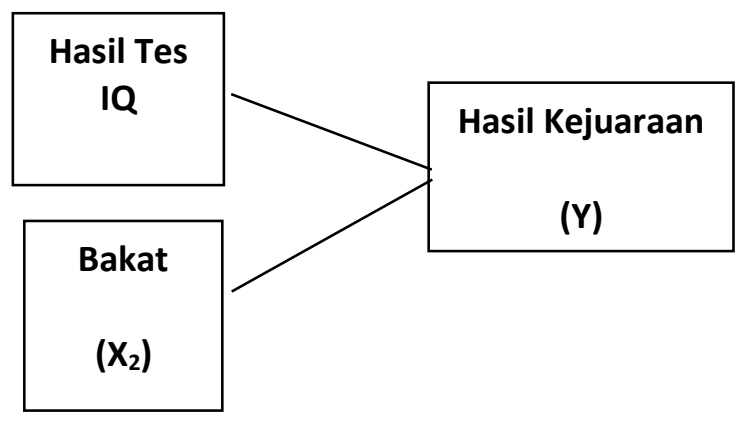

Gambar 1. Desain Penelitian

\section{Partisipan}

Populasi dalam penelitian ini adalah seluruh atlet senam artistik dan ritmik yang mengikuti kejuaraan POPDA senam di Yogyakarta. Sedangkan teknik sampling menggunakan purposive sampling dengan jumlah sampel 16 orang yang telah mengikuti seleksi daerah masing-masing.

\section{Instrumen}

Pada peneitian ini untuk mengukur tingkat Intelligence Quotient menggunakan instrumen tes Intelligence Quotient atau tes Stanford-Binet (Paolitto and Naglieri, 2004). Pengukuran variabel bakat menggunakan instrumen pemanduan bakat yang meliputi kekuatan, power, kelentukan, kecepatan, keseimbangan, 
dan koordinasi (Mahendra, Reksowiredjo, Diwayanti, 2002).

\section{Prosedur}

Teknik pengumpulan data yang digunakan adalah dengan metode survei dengan teknik tes dan pengukuran.

\section{Analisis Data}

Teknik analisis data pada penelitian ini meliputi: 1) Uji Prasyarat yang terdiri dari Uji Normalitas Data dan Uji Linearitas Data, 2) Uji Hipotesis menggunakan Uji Korelasi Product Moment dengan bantuan SPSS.

\section{HASIL}

Data dalam penelitian ini terdiri atas; 1) Hasil Tes IQ, 2) Hasil Tes Bakat dan 3) Skor Hasil Kejuaraan. Secara rinci hasil penelitian ini yaitu:

\section{Hasil Tes IQ}

Dalam penelitian ini menggunakan tes Intelligence Quotient atau biasa disebut tes StanfordBinet. Tes Stanford-Binet dikembangkan selama 7 tahun dengan hasil produk menjadi SB5. SB5 diterbitkan dengan fitur, norma, dan prosedur yang ditingkatkan.(Silverman et al., 2010)

Tabel 1. Data Hasil Penelitian

\begin{tabular}{cccc}
\hline No & Nama & Umur & IQ \\
\hline 1 & A & $10 \mathrm{Th}$ & 109 \\
2 & $\mathrm{~B}$ & $11 \mathrm{Th}$ & 108 \\
3 & $\mathrm{C}$ & $14 \mathrm{Th}$ & 108 \\
4 & $\mathrm{D}$ & $11 \mathrm{Th}$ & 105 \\
5 & $\mathrm{E}$ & $10 \mathrm{Th}$ & 105 \\
6 & $\mathrm{~F}$ & $13 \mathrm{Th}$ & 103 \\
7 & $\mathrm{G}$ & $12 \mathrm{Th}$ & 101 \\
8 & $\mathrm{H}$ & $15 \mathrm{Th}$ & 101 \\
9 & $\mathrm{I}$ & $14 \mathrm{Th}$ & 100 \\
10 & $\mathrm{~J}$ & $13 \mathrm{Th}$ & 99 \\
11 & $\mathrm{~K}$ & $15 \mathrm{Th}$ & 96 \\
12 & $\mathrm{~L}$ & $15 \mathrm{Th}$ & 94 \\
13 & $\mathrm{M}$ & $16 \mathrm{Th}$ & 93 \\
14 & $\mathrm{~N}$ & $08 \mathrm{Th}$ & 90 \\
15 & $\mathrm{O}$ & $10 \mathrm{Th}$ & 86 \\
16 & $\mathrm{P}$ & $10 \mathrm{Th}$ & 86 \\
\hline
\end{tabular}

Hasil penghitungan data IQ menghasilkan rerata sebesar 99.0, median $=105.0$, modus $=$ 86.0, dan standar deviasi $=7.52$. Adapun nilai terkecil sebesar 86.0 dan terbesar sebesar 109.0. Tabel distribusi IQ adalah sebagai berikut:
Tabel 2. Distribusi IQ

\begin{tabular}{|c|c|c|c|c|}
\hline No & Interval & Kategori & (n) & $(\%)$ \\
\hline 1 & $104.4-108.9$ & Sangat Baik & 6 & $37.5 \%$ \\
\hline 2 & $99.8-104.3$ & Baik & 3 & $18.75 \%$ \\
\hline 3 & $95.2-99.7$ & Cukup & 2 & $12.5 \%$ \\
\hline 4 & $90.6-95.1$ & Kurang & 2 & $12.5 \%$ \\
\hline 5 & $86.0-90.5$ & $\begin{array}{l}\text { Sangat } \\
\text { Kurang }\end{array}$ & 3 & $18.75 \%$ \\
\hline & \multicolumn{2}{|c|}{ Jumlah } & 16 & $100 \%$ \\
\hline
\end{tabular}

Berdasarkan tabel 2. terlihat bahwa sebagian besar IQ berada pada kategori sangat baik dengan persentase sebesar $37.5 \%$ dan masuk dalam kategori baik sebesar 18.75\%. Apabila ditampilkan dalam bentuk grafik, maka data IQ tampak pada gambar 2 sebagai berikut:

\section{Tingkat IQ}

\section{$100,00 \%$$$
50,00 \%
$$$$
18,75 \%{ }_{12,50 \%} 12,50 \% 18,75 \%
$$ \\ $0,00 \%$ \\ - Sangat Kurang $\square$ Kurang $\square$ Cukup $\square$ Baik $\square$ Sangat Baik \\ Gambar 2. Data Presentase Tingkat IQ}

\section{Hasil Tes Bakat}

Tes Bakat yang dilakukan terdiri atas kelentukan, kekuatan, koordinasi, keseimbangan, dan power, hasilnya dapat dilihat pada tabel 3 berikut ini.

Tabel 3. Deskripsi Statistik Bakat

\begin{tabular}{ccccccc}
\hline & K1 & K2 & K3 & K4 & K5 & Power \\
\hline $\mathrm{N}$ & 16 & 16 & 16 & 16 & 16 & 16 \\
Mean & 40.22 & 30.94 & 7.56 & 63.93 & 3.38 & 40.87 \\
Median & 40.5 & 29 & 7.5 & 64.34 & 3.49 & 42 \\
Mode & 40.5 & 21 & 6 & 29.57 & 2.45 & 32 \\
Std. Dev & 2.44 & 6.84 & 1.79 & 24.61 & 0.59 & 6.39 \\
Minimum & 35.5 & 21 & 5 & 29.57 & 2.45 & 29 \\
Maximum & 44.5 & 42 & 10 & 100.16 & 4.13 & 51 \\
\hline Ket: K1 & $=$ Kelentukan & & & \\
K2 & $=$ Kekuatan \\
K3 & $=$ Koordinasi \\
K4 & $=$ Keseimbangan \\
K5 & $=$ Kecepatan
\end{tabular}


Hasil penghitungan data tes bakat berdasarkan T-Score menghasilkan rerata sebesar 300.0 , median $=306.28$, modus $=240.01$, dan standar deviasi $=37.2$. Adapun nilai terkecil sebesar 240.01 dan terbesar sebesar 362.36. Tabel distribusi tes bakat berdasarkan T-Score sebagai berikut:

Tabel 4. Distribusi Bakat Berdasarkan T-Score

\begin{tabular}{ccccc}
\hline No & Interval & Kategori & Freq & (\%) \\
\hline 1 & $337.89-362.36$ & Sangat & 2 & $12.5 \%$ \\
2 & $313.42-337.88$ & Baik & & \\
3 & $288.95-313.41$ & Cukup & 1 & $6.25 \%$ \\
4 & $264.48-288.94$ & Kurang & 4 & $25 \%$ \\
5 & $240.01-264.47$ & Sangat & 3 & $18.75 \%$ \\
& & Kurang & & $\mathbf{1 6}$ \\
& Jumlah & & $\mathbf{1 0 0 \%}$ \\
\hline
\end{tabular}

Berdasarkan tabel 4. terlihat bahwa sebagian besar tes bakat berdasarkan T-Score berada pada kategori baik dengan persentase sebesar 37.5\% dan masuk dalam kategori baik.

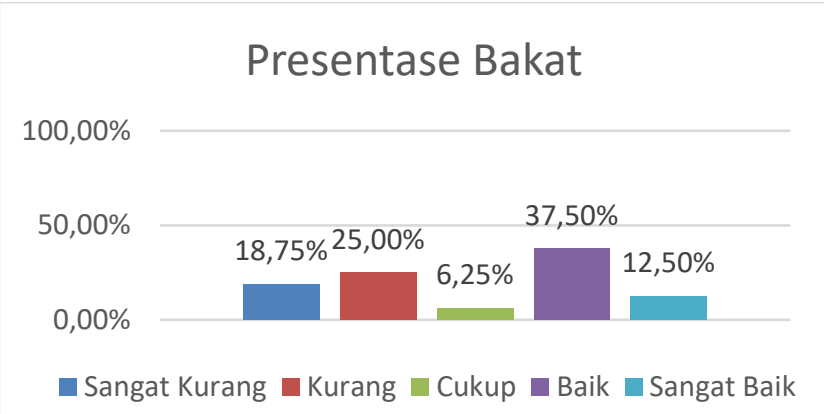

Gambar 3. Data Presentase Bakat

\section{Hasil POPDA Senam}

Hasil penghitungan data hasil senam menghasilkan rerata sebesar 8.34, median $=8.47$, modus $=4.58$, dan standar deviasi $=2.14$. Nilai terkecil yang diperoleh sebesar 4.48 dan nilai terbesar sebesar 11.22. Hasil selengkapnya dapat dilihat Tabel distribusi hasil senam sebagai berikut pada table 5 .
Tabel 5. Distribusi Frekuensi Hasil Senam

\begin{tabular}{|c|c|c|c|c|}
\hline No & Interval & Kategori & Freq & $(\%)$ \\
\hline 1 & $\begin{array}{l}9.892- \\
11.219\end{array}$ & Sangat Baik & 4 & $25 \%$ \\
\hline 2 & $8.564-9.891$ & Baik & 4 & $25 \%$ \\
\hline 3 & $7.236-8.563$ & Cukup & 2 & $12.5 \%$ \\
\hline 4 & $5.908-7.235$ & Kurang & 4 & $25 \%$ \\
\hline 5 & $4.58-5.907$ & $\begin{array}{l}\text { Sangat } \\
\text { Kurang }\end{array}$ & 2 & $12.5 \%$ \\
\hline & \multicolumn{2}{|c|}{ Jumlah } & 16 & $100 \%$ \\
\hline
\end{tabular}

Berdasarkan tabel 5 terlihat bahwa sebagian besar hasil senam berada pada kategori sangat baik, baik dan kurang dengan persentase sebesar 25\%. Gambaran hasil dapat dilihat pada diagram berikut ini.

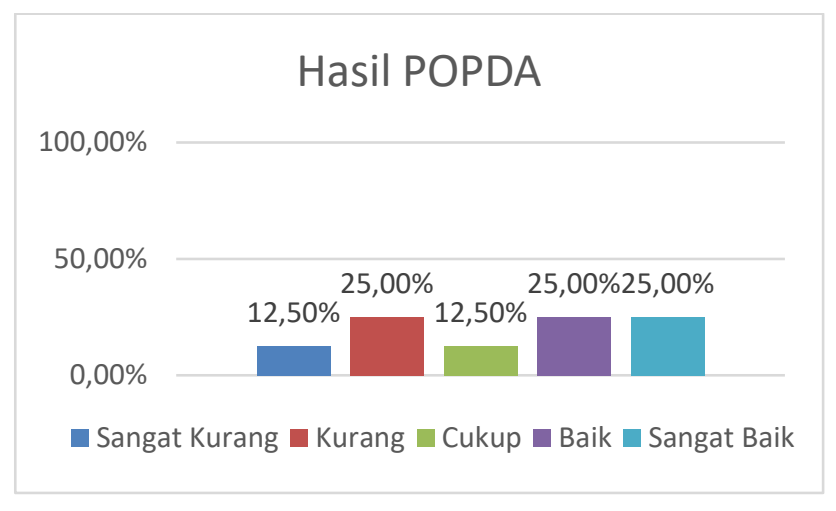

Gambar 4. Data Hasil POPDA

\section{Hasil Analisis Data Uji Prasyarat}

Analisis data untuk menguji hipotesis memerlukan beberapa uji persyaratan yang harus dipenuhi agar hasilnya dapat dipertanggungjawabkan. Uji persyaratan analisis meliputi:

\section{Uji Normalitas}

Uji normalitas variabel dilakukan dengan menggunakan rumus Kolmogorov-Smirnov. Rangkuman hasil uji normalitas dapat dilihat pada tabel 6 berikut ini. 
Tabel 6. Hasil Uji Normalitas

\begin{tabular}{cccc}
\hline Variabel & $\boldsymbol{p}$ & Sig. & Ket \\
\hline IQ & 0.964 & 0.05 & Normal \\
Hasil & 0.897 & 0.05 & Normal \\
Senam & & & \\
\hline
\end{tabular}

Dari tabel di atas, menunjukkan bahwa nilai signifikansi $(p)$ adalah lebih besar dari 0.05 , jadi, data berdistribusi normal. Sedangkan data pada variabel bakat sudah normal dengan sendirinya karena data ditransformasikan ke dalam T-Score. Oleh karena semua data berdistribusi normal maka analisis dapat dilanjutkan dengan analisis statistik parametrik.

\section{Uji Linearitas}

Pengujian linieritas hubungan dilakukan melalui uji F. Hubungan antara variabel $X$ dengan $\mathrm{Y}$ dinyatakan linier apabila nilai $\mathrm{F}$ tabel $>\mathrm{F}$ hitung dengan $\mathrm{db}=\mathrm{m} ; \mathrm{N}-\mathrm{m}-1$ pada taraf signifikansi $5 \%$. Hasil uji linieritas dapat dilihat dalam tabel 8 berikut ini.

Tabel 7. Hasil Uji Linieritas

\begin{tabular}{ccccc}
\hline Hubungan & \multicolumn{3}{c}{$\mathbf{F}$} & \multirow{2}{*}{ Ket } \\
\cline { 2 - 4 } Fungsional & Hitung & $\mathbf{d b}$ & Tabel & \\
$\mathrm{X}_{1} . \mathrm{Y}$ & 0.375 & $10 ; 4$ & 5.964 & Linier \\
\hline
\end{tabular}

Dari tabel di atas, terlihat bahwa nilai $\mathrm{F}$ hitung variabel IQ dengan variabel hasil senam (adalah lebih kecil dari F tabel. Jadi, hubungan variabel bebas dengan variabel terikatnya dinyatakan linear.

\section{Uji Hipotesis}

Analisis data penelitian yang digunakan untuk menguji hipotesis menggunakan rumus pearson product moment. Hasil uji hipotesis dalam penelitian ini sebagai berikut.

\section{Hubungan antara IQ dengan Hasil Senam}

Uji hipotesis yang pertama berbunyi "Tidak ada hubungan antara tingkat Intelligence quotient dengan hasil kejuaran POPDA senam DIY Tahun 2012". Hasil uji hipotesis dengan menggunakan analisis regresi korelasi dapat dilihat pada tabel 8 berikut ini.
Tabel 8. Koefisien Korelasi IQ ( $\left.\mathrm{X}_{1}\right)$ dengan Hasil Senam (Y)

\begin{tabular}{cccc}
\hline Korelasi & r hitung & r tabel & Ket \\
\hline $\mathrm{X}_{1} \mathrm{Y}$ & 0.325 & 0.400 & $\begin{array}{c}\text { Tidak } \\
\text { Signifikan }\end{array}$ \\
\hline
\end{tabular}

Berdasarkan hasil analisis tersebut di atas diperoleh koefisien korelasi antara tingkat Intelligence quotient dengan hasil kejuaran POPDA senam sebesar 0.325 , bernilai positif artinya semakin besar nilai yang mempengaruhi maka semakin besar nilai hasilnya. Uji keberartian koefisien korelasi tersebut dilakukan dengan cara mengonsultasi harga $r$ hitung dengan $r$ tabel, pada $\alpha=5 \%$ dengan $\mathrm{N}=16$ diperoleh $\mathrm{r}$ tabel sebesar 0.400 . Karena koefisien korelasi antara $r$ hitung $(0.325)<(0.412) \mathrm{r}$ tabel, berarti koefisien korelasi tersebut tidak signifikan, dengan demikian hipotesis yang berbunyi "Tidak ada hubungan antara tingkat Intelligence quotient dengan hasil kejuaran POPDA senam DIY Tahun 2012" diterima. Artinya tidak ada hubungan yang signifikan antara tingkat Intelligence quotient dengan hasil kejuaran POPDA senam DIY Tahun 2012.

\section{Hubungan antara Bakat dengan Hasil Senam}

Uji hipotesis yang kedua berbunyi "Ada hubungan antara bakat dengan hasil kejuaran POPDA senam DIY Tahun 2012". Hasil uji hipotesis dengan menggunakan analisis regresi korelasi dapat dilihat pada tabel 9 berikut ini.

Tabel 9. Koefisien Korelasi Bakat $\left(\mathrm{X}_{2}\right)$ dengan Hasil Senam (Y)

\begin{tabular}{cccc}
\hline Korelasi & r hitung & r tabel & Keterangan \\
\hline $\mathrm{X}_{1} . \mathrm{Y}$ & 0.882 & 0.400 & Signifikan \\
\hline
\end{tabular}

Berdasarkan hasil analisis tersebut di atas diperoleh koefisien korelasi antara bakat dengan hasil kejuaran POPDA senam sebesar 0.882, bernilai positif artinya semakin besar nilai yang mempengaruhi maka semakin besar nilai hasilnya. Uji keberartian koefisien korelasi tersebut dilakukan dengan cara mengonsultasi harga $r$ hitung dengan $r$ tabel, pada $\alpha=5 \%$ dengan $\mathrm{N}=16$ diperoleh $\mathrm{r}$ tabel sebesar 0.400. Karena koefisien korelasi antara $\mathrm{r}$ hitung $(0.882)>(0.400)$ 
$\mathrm{r}$ tabel, berarti koefisien korelasi tersebut signifikan, dengan demikian hipotesis yang berbunyi "Ada hubungan antara bakat dengan hasil kejuaran POPDA senam DIY Tahun 2012" diterima. Artinya ada hubungan yang signifikan antara bakat dengan hasil kejuaran POPDA senam DIY Tahun 2012.

\section{Hubungan antara IQ dan Bakat dengan Hasil Senam}

Uji hipotesis berbunyi "Ada hubungan antara tingkat Intelligence quotient dan bakat terhadap hasil kejuaran POPDA senam DIY Tahun 2012". Hasil uji hipotesis dengan menggunakan analisis regresi korelasi dapat dilihat pada tabel 10.

Tabel 10. Koefisien Korelasi antara X1 dan X2 terhadap Y

\begin{tabular}{|c|c|c|c|c|}
\hline Korelasi & r hit & F hit & $\begin{array}{c}\text { F tabel } \\
(0.05 \\
2 ; 13)\end{array}$ & Ket \\
\hline $\mathrm{X}_{1} \mathrm{X}_{2 . \mathrm{Y}}$ & 0.883 & 23.002 & 3.806 & Signifikan \\
\hline
\end{tabular}
dilakukan dengan cara mengonsultasi harga $\mathrm{F}$ hitung dengan $\mathrm{F}$ tabel, pada $\alpha=5 \%$ dengan derajat kebebasan 2;13 diperoleh $\mathrm{F}$ tabel sebesar 3.806. Karena koefisien korelasi antara $\mathrm{F}$ hitung (23.002) > (3.806) F tabel, berarti koefisien korelasi tersebut signifikan, dengan demikian hipotesis yang berbunyi Ada hubungan antara tingkat Intelligence quotient dan bakat terhadap hasil kejuaran POPDA senam DIY Tahun 2012, diterima. Artinya ada hubungan yang signifikan antara tingkat Intelligence quotient dan bakat terhadap hasil kejuaran POPDA senam DIY Tahun 2012.

Besarnya hubungan tingkat Intelligence quotient dan bakat terhadap hasil kejuaran POPDA senam DIY Tahun 2012 diketahui dengan cara nilai $r\left(r^{2} \times 100 \%\right)$. Nilai $r^{2}$ sebesar 0.780 , sehingga besarnya hubungan sebesar $78 \%$, sedangkan sisanya sebesar $22 \%$ dipengaruhi oleh faktor lain yang tidak diteliti dalam penelitian ini.

\section{PEMBAHASAN}

Penelitian ini bertujuan untuk mengetahui adakah hubungan antara tingkat intelligence quotient dan bakat terhadap hasil kejuaraan POPDA senam DIY tahun 2012. Analisis data penelitian yang digunakan untuk menguji hipotesis menggunakan analisis korelasi sederhana.

Pertanyaan yang pertama adalah "Ada hubungan antara tingkat Intelligence quotient dengan hasil kejuaran POPDA senam DIY Tahun 2012". Karena koefisien korelasi antara $\mathrm{r}$ hitung $(0.325)>(0.400) r$ tabel, berarti koefisien korelasi tersebut tidak signifikan. Dengan demikian hipotesis yang berbunyi "tidak ada hubungan antara tingkat Intelligence quotient dengan hasil kejuaran POPDA senam DIY Tahun 2012" diterima. Artinya tidak ada hubungan yang signifikan antara Tidak ada hubungan antara tingkat Intelligence quotient dengan hasil kejuaran POPDA senam DIY Tahun 2012. Adanya hubungan ini karena dalam senam tidak hanya satu komponen yang mendukung dalam hasil kejuaraan. Terdapat faktor-faktor yang mempengaruhi prestasi atlet diantaranya yaitu keadaan diri seseorang dan lingkungan. Di dalam penelitian yang dilakukan sebelumnya hanya merupakan pernyataan bahwa IQ berhubungan dengan hasil kejuaraan.

Pertanyaan yang kedua adalah "Ada hubungan antara bakat dengan hasil kejuaran POPDA senam DIY Tahun 2012". Karena koefisien korelasi antara $\mathrm{r}$ hitung $(0.882)>$ (0.400) $r$ tabel, berarti koefisien korelasi tersebut signifikan. Dengan demikian hipotesis yang berbunyi "Ada hubungan antara tingkat Intelligence quotient dengan hasil kejuaran POPDA senam DIY Tahun 2012" diterima. Artinya ada hubungan yang signifikan antara tingkat Intelligence quotient dengan hasil kejuaran POPDA senam DIY Tahun 2012. Adanya hubungan ini karena bakat sangat mendukung atlet untuk meraih prestasi maksimal. Dengan kemampuan bakat yang dimilki dan kemauan tinggi maka atlet akan memperoleh hasil kejuaran yang maksimal.

Pertanyaan yang ketiga berbunyi "ada hubungan antara tingkat Intelligence quotient dan bakat terhadap hasil kejuaran POPDA senam DIY Tahun 2012". Berdasarkan hasil penelitian menunjukkan bahwa ada hubungan yang 
signifikan antara tingkat Intelligence quotient dan bakat terhadap hasil kejuaran POPDA senam DIY Tahun 2012, dengan nilai F hitung (23.002) $>$ (3.806) $\mathrm{F}$ tabel, berarti koefisien korelasi tersebut signifikan, dengan demikian hipotesis yang berbunyi "ada hubungan antara tingkat Intelligence quotient dan bakat terhadap hasil kejuaran POPDA senam DIY Tahun 2012" diterima. Artinya ada hubungan yang signifikan antara tingkat Intelligence quotient dan bakat terhadap hasil kejuaran POPDA senam DIY Tahun 2012.Terdapat hasil penelitian dari Yulianto \&Nashori (2006) yaitu terdapat hubungan yang signifikan antara kepercayaan diri dengan prestasi.

\section{KESIMPULAN}

Berdasarkan hasil analisis data, deskripsi, pengujian hasil penelitian, dan pembahasan, dapat diambil kesimpulan bahwa 1) Tidak ada hubungan antara tingkat Intelligence quotient dengan hasil kejuaran POPDA senam DIY Tahun 2012, 2) Ada hubungan antara tingkat bakat dengan hasil kejuaran POPDA senam DIY Tahun 2012 dan 3) Ada hubungan antara tingkat Intelligence quotient dan bakat terhadap hasil kejuaran POPDA senam DIY Tahun 2012.

\section{REFERENSI}

Abbott, A. et al. (2002) 'Talent Identification and Development: An Academic Review A report for sportscotland by The University of Edinburgh', Sport Scotland, (August), pp. $1-103$.

American Sport Education Program and USA Gymnastics (2011) Coaching youth gymnastics. United States: Human Kinetics.

Andiri, L., Jajat, , and Sultoni, K. (2017) 'Hubungan Kecerdasan Emosi dengan Prestasi Akademik Mahasiswa Olahraga', Jurnal Terapan Ilmu Keolahragaan, 2(2), p. 137. doi: 10.17509/jtikor.v2i2.8063.

Endepohls-Ulpe, M. (2009) 'Teaching Gifted and Talented Children', in International Handbook of Research on Teachers and Teaching. doi: 10.1007/978-0-387-73317-
3_57.

Fazari, M., Damayanti, I. and Rahayu, N. I. (2017) 'Hubungan Kecerdasan Intelektual (Iq) Dan Kecerdasan Emosional (Eq) Dengan Keterampilan Bermain Dalam Cabang Olahraga Bulutangkis', Jurnal Terapan Ilmu Keolahragaan, 2(1), p. 33. doi: 10.17509/jtikor.v2i1.5350.

Festiawan, R. (2020) 'Pendekatan Teknik dan Taktik: Pengaruhnya Terhadap Keterampilan Bermain Futsal', Gelanggang Olahraga: Jurnal Pendidikan Jasmani dan Olahraga, 3(2), pp. 143-155. doi: https://doi.org/10.31539/jpjo.v3i2.1080.

International Gymnastics Federation (F.I.G) (2016) '2017-2020 Code of Points', in FIG Executive Committee (ed.) 2017-2020 CODE OF POINTS. FIG Executive Committe.

Mahendra, Reksowiredjo, Diwayanti, A. (2002) Pemanduan bakat olahraga senam (artistik dan ritmik). Edited by K. T. P. Persani. Jakarta: Depdiknas.

Makel, M. C. et al. (2015) 'Gifted Students' Implicit Beliefs About Intelligence and Giftedness', Gifted Child Quarterly. doi: 10.1177/0016986215599057.

Mkaouer, B. et al. (2018) 'Evaluating the physical and basic gymnastics skills assessment for talent identification in men's artistic gymnastics proposed by the International Gymnastics Federation', Biology of Sport. doi: 10.5114/biolsport.2018.78059.

Paolitto, A. W. and Naglieri, J. A. (2004) 'Stanford-Binet Intelligence Scale.', in Encyclopedia of psychology, Vol. 7. doi: 10.1037/10522-192.

Pion, J. et al. (2015) 'Talent in Female Gymnastics: A Survival Analysis Based upon Performance Characteristics', International Journal of Sports Medicine. doi: $10.1055 / \mathrm{s}-0035-1548887$.

Preckel, F., Holling, H. and Wiese, M. (2006) 'Relationship of intelligence and creativity in gifted and non-gifted students: An investigation of threshold theory', 
Personality and Individual Differences. doi: 10.1016/j.paid.2005.06.022.

Silverman, W. et al. (2010) 'Stanford-Binet and WAIS IQ differences and their implications for adults with intellectual disability (aka mental retardation)', Intelligence. doi:

10.1016/j.intell.2009.12.005.

Tucker, R. and Collins, M. (2012) 'What makes champions? a review of the relative contribution of genes and training to sporting success', British Journal of Sports Medicine. doi: 10.1136/bjsports-2011090548.

Werner, P. H., Williams, L. H. and Hall, T. J. (2012) Teaching children gymnastics.

Yulianto, F. and Nashori F. (2006). Kepercayaan diri dan Prestasi Atlet Taekwondo Daerah Istimewa Yogyakarta. Jurnal Psikologi Universitas Diponegoro Vol.3 No. 1, Juni 2006 